\title{
NXPE1 Gene
}

National Cancer Institute

\section{Source}

National Cancer Institute. NXPE1 Gene. NCI Thesaurus. Code C131200.

This gene may play a role in lipid metabolism. 